\title{
Recent significant decline of strong carbon peat accumulation rates in tropical Andes related to climate change and glacier retreat
}

\author{
Romina Llanos ${ }^{1}$, Patricia Moreira-Turcq ${ }^{1,2}$, Bruno Turcq ${ }^{3}$, Raúl Espinoza Villar ${ }^{1,4}$, Yizet Huaman ${ }^{4}$, \\ Thomas Condom ${ }^{5}$, Bram Willems ${ }^{4}$ \\ $5 \quad{ }^{1}$ Universidad Nacional Agraria La Molina (UNALM), Lima, 15012, Peru \\ ${ }^{2}$ Institut de Recherche pour le Développement (IRD), Géosciences Environnement Toulouse (GET), UMR 5563, Toulouse, \\ France \\ ${ }^{3}$ Institut de Recherche pour le Développement (IRD), LOCEAN/IPSL-Sorbonne Université, Bondy, 93141, France \\ ${ }^{4}$ Centro de Competencia del Agua (CCA), Programa Agua-Andes, Lima, 15086, Peru \\ $10 \quad{ }^{5}$ Université Grenoble Alpes, IRD, CNRS, IGE-UMR 5001, Grenoble, France
}

Correspondence to: Romina Llanos (rominallanos@outlook.com)

\begin{abstract}
Climate change has altered precipitation and temperature patterns in the tropical Andes. As a result, tropical glaciers have retreated significantly over the past 50 years and have even disappeared in some areas. Andean peatlands, one of the most important Andean carbon reservoirs, also seem to be affected by these climate changes, since glaciers have been

15 recognized as one of their vital water sources. Here, we point out the important role of Andean peatlands on carbon accumulation rates (CAR), one of the highest in the world, and the impact of climate on carbon storage over the last 65 years, using four peat cores. The peat cores were radiocarbon-dated and ages were post-bomb calibrated and chronological models indicated basal ages (30 cm depth) ranging from 1957 to $1972 \mathrm{CE}$, where accumulation rates reached up $1.7 \mathrm{~cm} \mathrm{yr}^{-1}$. For both peatlands, carbon accumulation rates are high (mean of 470 and $220 \mathrm{~g} \mathrm{C} \mathrm{m}^{-2} \mathrm{yr}^{-1}$ at APA 1 and APA 2 sites,

20 respectively) and can reach up to $1010 \mathrm{~g} \mathrm{C} \mathrm{m}^{-2} \mathrm{yr}^{-1}$. Distichia muscoides is the dominant species in the Peruvian Central Andes peatlands and the high CAR, among other factors, is a characteristic of this species. Our results point out that a marked decrease of CAR after the early 1980s at both peatlands is likely related to an increase in annual temperature, which is responsible for the retreat of glaciers. We use a new high-resolution proxy (Skrzypek et al., 2011) based on the $\delta^{13} \mathrm{C}$ of Distichia along the cores to evaluate the temperature variability at the site. We observed a general trend of increase in the 25 reconstructed temperature from both studied peatlands from 1.9 to $2{ }^{\circ} \mathrm{C}$ for the period $1970-2015 \mathrm{CE}$. Comparison with air temperature data from the NCEP-NCAR reanalysis for the higher resolution cores shows a good relationship and an increase of $2.15^{\circ} \mathrm{C}$ for the same period. Temperature increase may directly affect CAR by an increase in organic matter degradation rates. The decrease in CAR during the period of study may also be due to a decrease in melt water inflow generated by the retreat of glaciers that have almost disappeared today in the catchments as a consequence of regional warming. Our findings 30 emphasize that marked changes in carbon accumulation rates demonstrate the high ecological sensitivity of tropical highAndean peatlands, endangering their outstanding role in the regional (and even global) $\mathrm{C}$ cycle as large $\mathrm{C}$ sinks that contribute to the mitigation of global climate change.
\end{abstract}


https://doi.org/10.5194/bg-2022-47

Preprint. Discussion started: 21 February 2022

(c) Author(s) 2022. CC BY 4.0 License.

(c) (i)

\section{Introduction}

Peatlands are the largest organic carbon (C) terrestrial reservoirs, covering approximately $3 \%$ of the Earth's surface and containing about 25\% (600 Gt C) of the global soil C stock (Yu et al., 2010; Xu et al., 2018). The amount of C stored in peatlands is similar to the total $\mathrm{C}$ stocks in all living biomass or in the atmosphere (Yu et al., 2016) and is equivalent to twice the quantity stored in the global forest biomass (Pan et al., 2011). Even though peatlands worldwide play an important role in the $\mathrm{C}$ cycle and many of them have been the focus of scientific researches, the $\mathrm{C}$ and vegetation dynamics of high-Andean cushion-dominated peatlands are still poorly understood.

40 In Andean peatlands, cushion-forming vascular plants, dominated by Distichia muscoides (Schittek et al., 2018), are found in areas with poor drainage or with a positive hydrological balance at very high elevations (Kleinebecker et al., 2010). They are the dominant component of the vegetation of high-mountain peatlands of the Andes at elevations between 3500 and $5100 \mathrm{~m}$ asl, due to its adaptability to the freezing conditions and harsh windy associated with high Andean ecosystems. High-altitude tropical peatlands represent one of the most important water reservoirs, providing outstanding environmental services that contribute to maintenance of biodiversity in the Andes and the welfare of local human populations (Chimner \& Karberg, 2008; Salvador et al., 2014). Their most important ecological role is to accumulate organic C by controlling decomposition processes in the soil (Muñoz García and Faz Cano, 2012; Cooper et al., 2015), but they are now among the ecosystems most vulnerable to climatic changes (Charman et al., 2013). Recent study on Andean peatlands (Huaman et al., 2020) have shown significant variations in $\mathrm{C}$ accumulation over the last 3000 years $\mathrm{BP}$, which is correlated with the occurrence of extreme precipitation events, moreover drier or wetter and/or warmer or colder phases are also related to periods of advance and/or retreat of tropical glaciers.

More than $99 \%$ of the glaciers in the world's tropical latitudes are located in the central Andes, with $70 \%$ of them in Peru (Chevallier et al., 2010). In the high Andes, climate change has altered precipitation and temperatures patterns (Rabatel et al., 2013; Vuille et al., 2018). As a consequence, tropical glaciers have dramatically withdrawn over the past decades and have almost disappeared in many areas (Jomelli et al., 2009; Rabatel et al., 2013; Vuille et al., 2008; 2018). Compared to glaciers in temperate or polar regions, tropical glaciers are particularly sensitive to climate variations, as they are subject to considerably higher levels of energy forcing because they are located at low latitudes and then at higher altitude. In addition, the period of maximum precipitation coincides with summer, resulting in snow accumulation at the highest elevations, but rapid melting at the lowest elevations because of the relatively high temperatures (Kaser and Ostmaston, 2002; Chevallier et

60 al., 2010).

In this context of global and regional climatic changes, with temperature on the rise and changes observed in the seasonal distribution of precipitation (Vuille et al., 2018), the Peruvian Andes are particularly vulnerable as they contain little glacier coverage and rely on seasonal water storage from wetlands and permafrost to recharge the headwaters (Vuille et al., 2003). The sensitivity of glacier coverage is demonstrated by the trend in the changes in their mass balance, which has been quite negative over the past 50 years, slightly more negative than the trend computed at a global scale. A break point in the trend 
https://doi.org/10.5194/bg-2022-47

Preprint. Discussion started: 21 February 2022

(c) Author(s) 2022. CC BY 4.0 License.

\section{(c) (i)}

appeared in the late 1970s, when the retreat accelerated. Before that date, changes in glacier length were limited. Since the end of the 1970s, however, glacial withdrawal has increased, with the glaciers retreating at more than twice the rate of the former period, between 500 and 700m in length (Rabatel et al., 2013). This is especially negative for high-mountain peatlands in the Andes because tropical glaciers have been recognized as one of the main water sources for them, maintaining a stable water table through the year (Thompson et al., 2006; Benavides et al., 2013).

In this study, we assessed the impact of climate change on high mountains peatlands in the Central Andes of Peru, pointing out negative consequences on one of the major $\mathrm{C}$ reservoirs not yet well known in the Andean region. We used a new paleoclimate proxy based on changes of $\mathrm{C}$ stable isotope to assess past temperature trends. Finally, these new information show how environmental and climate changes and its effects (as the accelerated glacial withdrawal) can affect peatlands and also how altered peatlands can affect the carbon cycle in the future.

\section{Study Area}

Two tropical high-elevation peatlands (APA 1, $4200 \mathrm{~m}$ asl and APA 2, $4420 \mathrm{~m}$ asl) were studied in Apacheta region in the central Andes of Peru, between $13^{\circ} 20^{\prime} \mathrm{S}$ and $13^{\circ} 21^{\prime} \mathrm{S}$, and $74^{\circ} 39^{\prime} \mathrm{W}$ and $74^{\circ} 40^{\prime} \mathrm{W}$ (Fig. 1). APA 1 is located in a subcatchment with an area of $130 \mathrm{~km}^{2}$, with an elevation ranging from 4200 to $5000 \mathrm{~m}$ asl, while APA 2 sub-catchment had an

80 area of only $2.5 \mathrm{~km}^{2}$, with an elevation ranging from 4350 to $4850 \mathrm{~m}$ asl.

In this region, the vegetation is dominated by Distichia muscoides Nees \& Meyen, a Juncaceae species present on most highelevation peatlands in the central Peruvian Andes (Schittek et al., 2015). D. muscoides is a dioecious semiaquatic plant that grows in dense cushions (Buffen et al., 2009; Skrzypek et al., 2011; Schittek et al., 2018). It has an altitudinal vegetation limit between 3500 and $5100 \mathrm{~m}$ asl. Distichia leaves are 3 to $7 \mathrm{~mm}$-long, are inserted densely along the stem and form hard monticules (diameter: $\sim 2 \mathrm{~m}$ ), which are compact mats surrounded by flooded hollows that are permanently bare of vegetation (Balslev, 1996). This species is well adapted to the high-elevation Andean climate and is able to survive diurnal cycles of freezing and thawing (Buffen et al., 2009). Distichia cushions may have started to form as a single individual, producing a large number of shoots and rhizomes, which later transformed into smaller groups as the underground parts of the plant died off (Schittek et al., 2018).

90 The climate of the Apacheta peatlands is typical of tropical high mountains with little seasonal variations in temperature and large seasonal precipitation variability. Based on data from the Apacheta station located near the two Andean peatlands of this study, about $1.6 \mathrm{~km}$, at $13^{\circ} 20^{\prime} 51^{\prime \prime} \mathrm{S}, 74^{\circ} 38^{\prime} 44^{\prime \prime} \mathrm{W}$ and $4150 \mathrm{~m}$ asl, the study area presents an average annual precipitation of $830 \mathrm{~mm}$ for the period 1991-2012 CE and is marked by seasonal precipitation, with the wettest months being from October to March (monthly average: $114 \mathrm{~mm}$ ). This seasonal pattern of rainfall reflects the occurrence of South

95 American Monsoon during South Hemisphere summer. The mean annual temperature of the upper part of the basin is $6.4^{\circ} \mathrm{C}$ for the period 2000-2014 CE, with monthly averages ranging from 4.8 to $7.6^{\circ} \mathrm{C}$; and the annual average relative humidity is 70.3\% (for the period 2009-2013 CE) (GORE Ayacucho, 2015). 


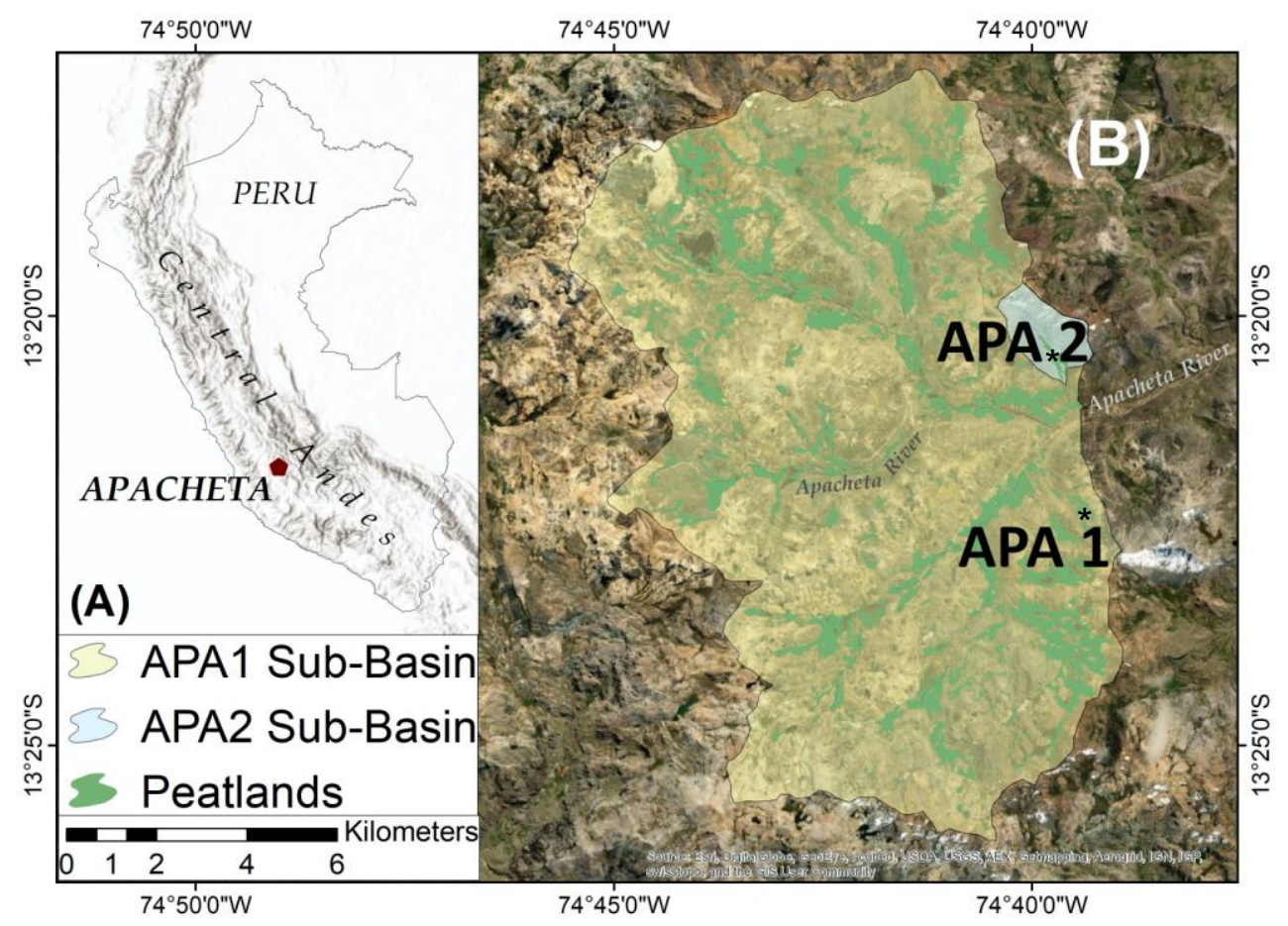

100 Figure 1: (A) Location of the study peatland area, Apacheta, in the Central Andes of Peru. (B) The sub-basins of the two peatlands are delineated, and the location of the peat cores in APA1 (4200 m asl.) and APA2 (4420 m asl.) are pointed by a black star (Source: Esri, DigitalGlobe, GeoEye, i-cubed, USDA, USGS, AEX, Getmapping, Aerogrid, IGN, IGP, swisstopo, and the GIS User Community).

\section{Materials and Methods}

105 For this study, four short peat cores between 29 and $35 \mathrm{~cm}$-long were collected: APA1-C1 and APA1-C5 from the site located at an altitude of 4200 meters (APA 1), and, APA2-C3 and APA2-C4 from the other peatland at 4420 meters (APA 2) (Fig. 1). The peat cores were collected manually using PVC tubes $50 \mathrm{~cm}$ long and $8 \mathrm{~cm}$ in diameter, with sharpened edges to facilitate penetration and avoid compaction. Compression of the cores was minimal (or non-existent) because of the natural rigidity characteristic of the Distichia plant. The short cores were opened longitudinally in the laboratory. Soon after opening, the peat was sampled in aluminum U-channels to determine peat bulk density and water content. Sub-samples were taken at $1 \mathrm{~cm}$ intervals along the cores, and the water content was measured after oven drying at $50{ }^{\circ} \mathrm{C}$ for a few days to obtain a final stable weight. Bulk density $\left(\mathrm{g} \mathrm{cm}^{-3}\right)$ was calculated by dividing the dry weight by the volume of these fresh sub-samples.

Samples were dated using an accelerator mass spectroscopy (AMS) at the "Laboratoire de Mesure du Carbone 14 (LMC14) -

115 UMS 2572 (CEA/DSM CNRS IRD IRSN - Ministère de la Culture et de la Communication)" in Gif sur Yvette (France) and 
at the Radiocarbon Dating Laboratory Beta Analytic in Miami, Florida (USA). All radiocarbon ages were modern (post-CE 1950), so they were calibrated using CALIBomb, available at http://calib.org/CALIBomb, which is based on a compilation of atmospheric ${ }^{14} \mathrm{C}$ based on comprehensive and reliable radiocarbon data derived from atmospheric samples and tree-ring series for the period from 1950 to 2010 CE (Hua et al., 2013). Because of the location of our study sites, the Shcal13.f14c

120 data set for Southern Hemisphere Zone 1 - 2 was applied. The age - depth model was built using Clam (Code non-Bayesian, 'classical' age - depth models) (Blaauw, 2010). The chronological models of all four short cores were determined using a smooth spline regression.

Peat sections (3 $\mathrm{cm}$ long) from each short cores were analyzed for organic matter (OM) concentration (\%) by burning the samples in a muffle furnace at $550{ }^{\circ} \mathrm{C}$ for 5 hours (LOI: loss on ignition). TOC content of the peat samples was estimated using the conversion formula (Eq. 1) for Disticha muscoides peatlands published by Cooper et al. (2015) ( $\mathrm{R}^{2}$ : 0.92):

TOC $(\%)=0.53 * O M(\%)$,

$\mathrm{C}$ stable isotope composition $\left(\delta^{13} \mathrm{C}\right.$ in \%o) was determined using an isotope ratio mass spectrometer (Micromass Optima)

130 from the University of California-Davis (USA) and from the IRD-Bondy Research Center (France).

Carbon accumulation rates (CAR in $\mathrm{g} \mathrm{C} \mathrm{m}^{-2} \mathrm{yr}^{-1}$ ) were determined by multiplying the bulk density, accumulation rate and TOC content (Lähteenoja et al., 2009; Cooper et al., 2015; Xing et al., 2015).

We used new stable isotope paleoclimate proxy $\left(\delta^{13} \mathrm{C}\right)$ based on a strong relationship found between the $\mathrm{C}$ stable isotope composition of Distichia and air temperature (Skrzypek et al. 2011). They found that the $\delta^{13} \mathrm{C}$ value increases when 135 temperature decreases at about $-0.97 \pm 0.23 \% /{ }^{\circ} \mathrm{C}$ for Distichia peat $\left(\mathrm{R}^{2}: 0.86\right)$. This value was similar to the previously reported range for other species (included Sphagnum peat: -0.5 to $-0.6 \% /{ }^{\circ} \mathrm{C}$ ), and can be used to estimate relative paleotemperature changes recorded in Andean Distichia peat, as they mentioned.

Finally, we used the NCEP-NCAR reanalysis precipitation and temperature monthly data for the period 1948-2021 CE (at geopotential equals to $600 \mathrm{mb}$ ) for the zone that extend from $12^{\circ} 30^{\prime} \mathrm{S}$ to $12^{\circ} 54^{\prime} \mathrm{S}$ and $73^{\circ} 30^{\prime} \mathrm{W}$ to $73^{\circ} 95^{\prime} \mathrm{W}$

140 (https://www.esrl.noaa.gov/) (Kalnay et al., 1996) for the climate analysis because in the study area there were no meteorological data for a continuous long time series covering at least the last six decades, necessary to compare the meteorological conditions with the analysis of the peat cores.

\section{Results}

Twelve ${ }^{14} \mathrm{C}$ dating (AMS) samples (Table 1) were used to determine the chronology for the four peat cores. For cores from

145 APA 1, the chronological model indicated a basal age of $1971 \mathrm{CE}$ at $30 \mathrm{~cm}$ depth, while the ones from APA 2 dated to 1957 $\mathrm{CE}$ at the same depth (Fig. 2). All cores showed rapid growth rates of Distichia, with the highest values at the base (maximum value: $1.7 \mathrm{~cm} \mathrm{yr}^{-1}$ ) and an abrupt change occurred at the end of the 1970s, when the rates visibly decreased. 
https://doi.org/10.5194/bg-2022-47

Preprint. Discussion started: 21 February 2022

(c) Author(s) 2022. CC BY 4.0 License.

Table 1: AMS ${ }^{14} \mathrm{C}$ data post-modern carbon (pMC) and calibrated ages (with 2 sigmas) of the four peat cores.

\begin{tabular}{clcccc}
\hline Core & $\begin{array}{c}\text { Laboratory } \\
\text { Code }\end{array}$ & $\begin{array}{c}\text { Core depth } \\
(\mathbf{c m})\end{array}$ & pMC & Error pMC & $\begin{array}{c}\text { Calibrated ages (cal } \\
\text { years CE, } \\
\end{array}$ \\
& & & & 2 sigmas) \\
\hline APA1-C1 & Beta -54412 & $3-4$ & 105,73 & 0,2333 & $\mathbf{2 0 0 9}$ \\
& Beta -54413 & $15-16$ & 126,58 & 0,2607 & $\mathbf{1 9 8 2}$ \\
& Beta -54414 & $30-31$ & 143,77 & 0,2708 & $\mathbf{1 9 7 4}$ \\
APA1-C5 & SacA43156 & $2-3$ & 105,71 & 0,3829 & $\mathbf{2 0 0 9}$ \\
& SacA43157 & $12-13$ & 119,94 & 0,3351 & $\mathbf{1 9 8 6}$ \\
& SacA43158 & $26-27$ & 145,62 & 0,3717 & $\mathbf{1 9 7 3}$ \\
APA2-C3 & Beta -54415 & $2-3$ & 106,09 & 0,2244 & $\mathbf{2 0 0 9}$ \\
& Beta -465506 & $11-12$ & 120,08 & 0,4500 & $\mathbf{1 9 8 6}$ \\
& Beta -465507 & $32-33$ & 104,32 & 0,3900 & $\mathbf{1 9 5 7}$ \\
APA2-C4 & Beta -54409 & $2-3$ & 105,63 & 0,2870 & $\mathbf{2 0 0 9}$ \\
& Beta -54410 & $16-17$ & 123,01 & 0,2521 & $\mathbf{1 9 8 4}$ \\
& Beta -54411 & $30-31$ & 103,89 & 0,2373 & $\mathbf{1 9 5 7}$ \\
\hline
\end{tabular}


https://doi.org/10.5194/bg-2022-47

Preprint. Discussion started: 21 February 2022

(c) Author(s) 2022. CC BY 4.0 License.

(c) (i)

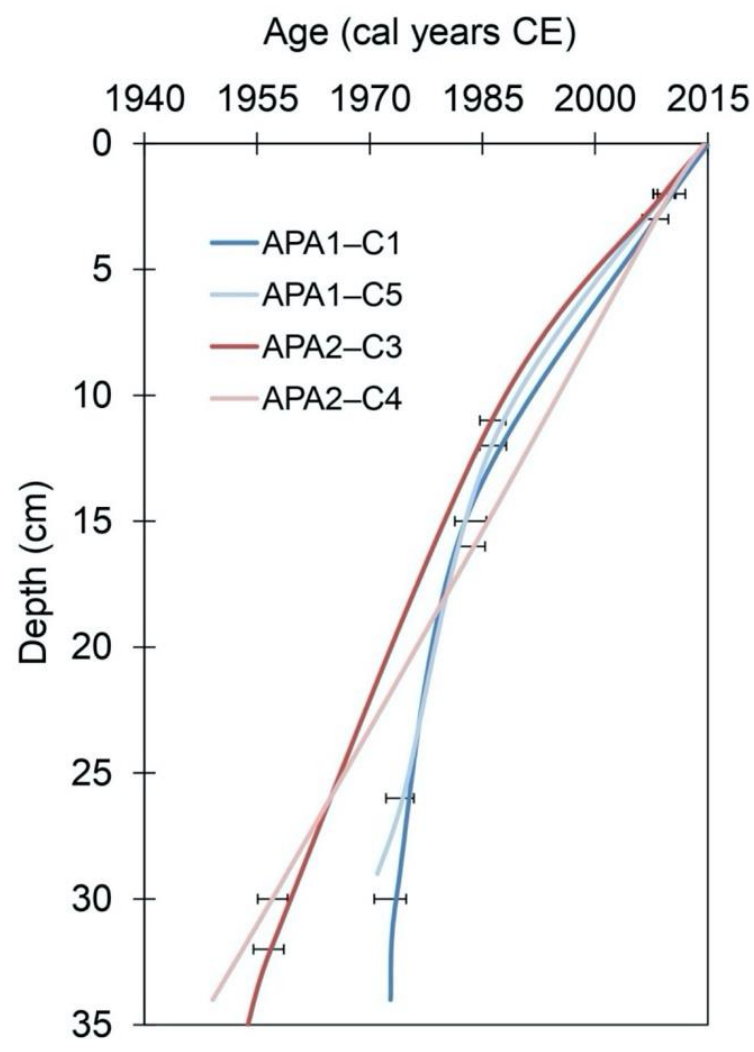

Figure 2: Age-depth models of peat cores (APA1-C1, APA1-C5, APA2-C3 and APA2-C4) based on post-bomb radiocarbon ages calculated with CALIB BOMB software ((http://calib.qub.ac.uk/CALIBomb/) using a smooth spline regression estimated by ClamR (Blaauw, 2010).

Mean bulk density (Supplementary Table 1) of the peat cores from APA 1 was $0.1084 \mathrm{~g} \mathrm{~cm}^{-3}$ (SD: $0.0499 \mathrm{~g} \mathrm{~cm}^{-3}$ ). For the cores from APA 2 the average was $0.0767 \mathrm{~g} \mathrm{~cm}^{-3}$ (SD: $0.0242 \mathrm{~g} \mathrm{~cm}^{-3}$ ). Both values were similar to those found in peatlands dominated by Distichia muscoides in Bolivia (Cooper et al., 2015).

In Peruvian peatlands, mean organic matter was very high (96\% for APA1 and 92\% for APA2) (Fig. 3). Mean TOC content resulted slightly greater for APA 1 than for APA 2 (51.0\% and 48.6\%, respectively) (Supplementary Table 1). However, there was a general upward trend in TOC content from the peat basal depth of the cores from both studied peatlands to approximately $13 \mathrm{~cm}$ (the early 1980s) and then the TOC values decreased to the top of the cores (2015 CE) (Supplementary 165 Fig. 1). 


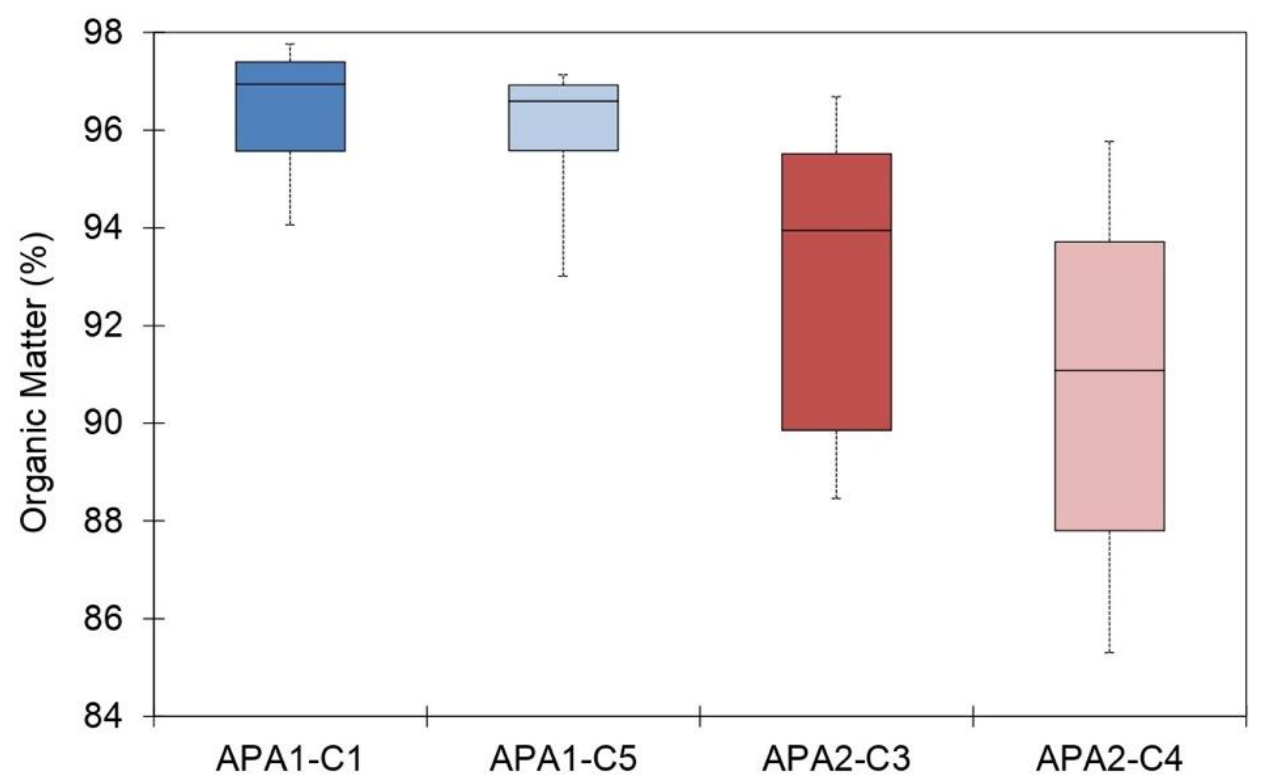

Figure 3: Box-Plot of organic matter content $(\%)$ for the four peat cores analyzed.

CAR varied depending on age and elevation. At APA 1, mean CAR were higher that at APA 2 (Supplementary Table 1),

175 reaching a maximum of $1010 \mathrm{~g} \mathrm{C} \mathrm{m}^{-2} \mathrm{yr}^{-1}$, with an average of $470 \mathrm{~g} \mathrm{C} \mathrm{m}^{-2} \mathrm{yr}^{-1}$. The cores from APA 2, APA2-C3 and APA2$\mathrm{C} 4$, had a mean CAR of 240 and $195 \mathrm{~g} \mathrm{C} \mathrm{m}^{-2} \mathrm{yr}^{-1}$, respectively (average: $220 \mathrm{~g} \mathrm{C} \mathrm{m}^{-2} \mathrm{yr}^{-1}$ ).

Highly variable CAR values were found from 34 to $16 \mathrm{~cm}$ (1971 to $1983 \mathrm{CE}$ ) for cores from APA 1 site (SD: $165 \mathrm{~g} \mathrm{C} \mathrm{m}^{-2}$ $\mathrm{yr}^{-1}$ ). From $16 \mathrm{~cm}$ to the top of the cores, mean CAR dropped to near present values of $325 \mathrm{~g} \mathrm{C} \mathrm{m}^{-2} \mathrm{yr}^{-1}$ (Fig. 4A). For APA 2's cores, from the peat basal depth to $14 \mathrm{~cm}$ (1951 to $1984 \mathrm{CE})$, average CAR diminished with a significant lower

180 variability (SD: $60 \mathrm{~g} \mathrm{C} \mathrm{m}^{-2} \mathrm{yr}^{-1}$ ) than in the peat section $34-16 \mathrm{~cm}$ from APA 1's cores. For the upper $14 \mathrm{~cm}$ of peat, CAR values slightly decreased to the top of the cores (mean CAR: $150 \mathrm{~g} \mathrm{C} \mathrm{m}^{-2} \mathrm{yr}^{-1}$ ) (Fig. 4B). 


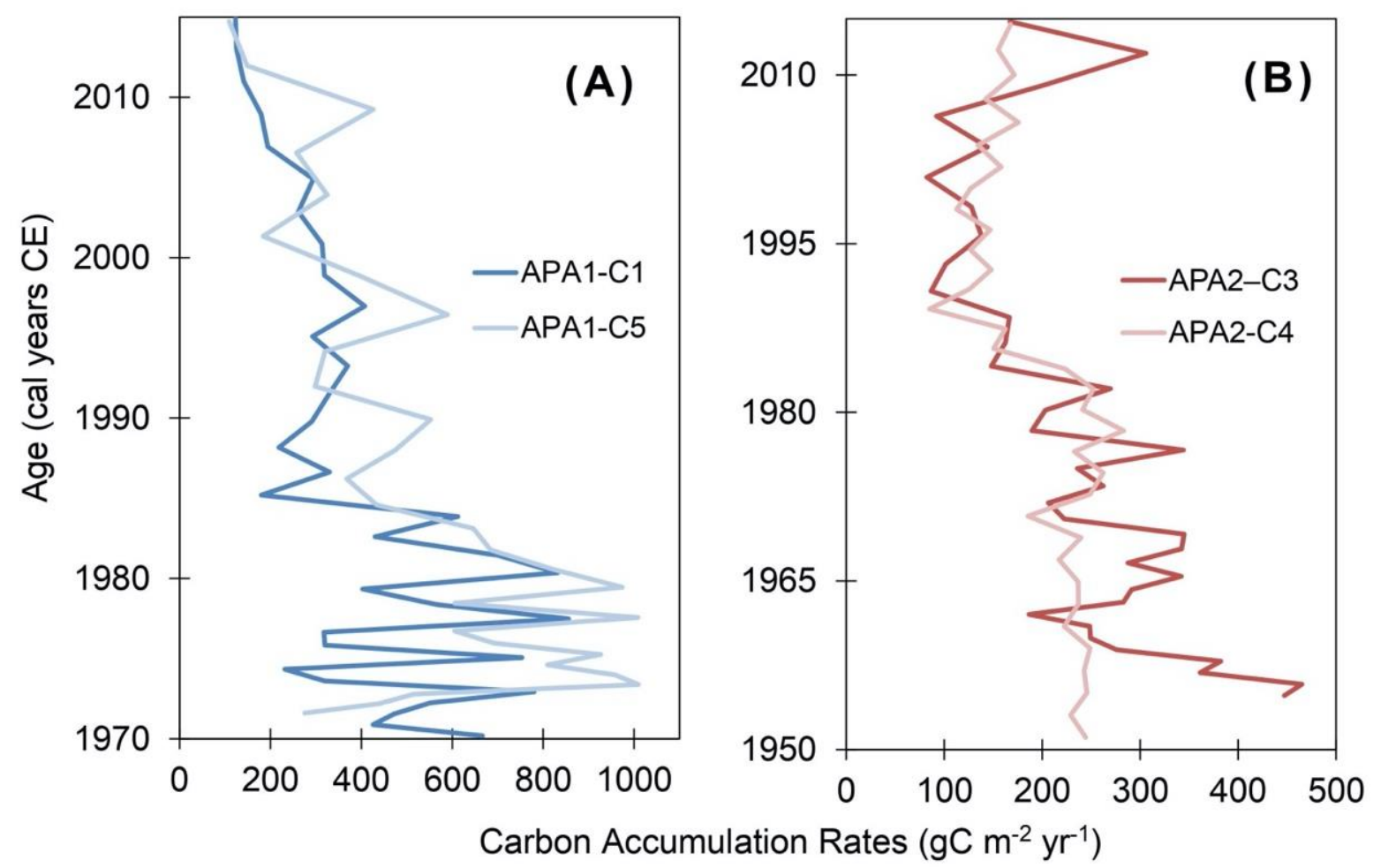

Figure 4: Carbon accumulation rates (CARs) over time in the high-Andean peatlands for the analyzed cores: (A) APA1-C1 and APA1-C5 at $4200 \mathrm{~m}$ a.s.l. and (B) APA2-C3 and APA2-C4 at $4420 \mathrm{~m}$ a.s.l.

Stable isotopes analysis indicated $\delta^{13} \mathrm{C}$ (Supplementary Table 1) values ranging from -27.70 to $-24.44 \%$, consistent with $\mathrm{C}_{3}$ plant composition for all the peat cores: mean value for APA1-C5 was -25.72\% (SD: 1.01\%) and for APA2-C4 the average was $-26.83 \%$ (SD: $0.60 \%$ ). At both peatlands, there was a general trend to more negative $\delta 13 \mathrm{C}$ values from the basal depth 190 to the top of the cores (Fig. 5). 


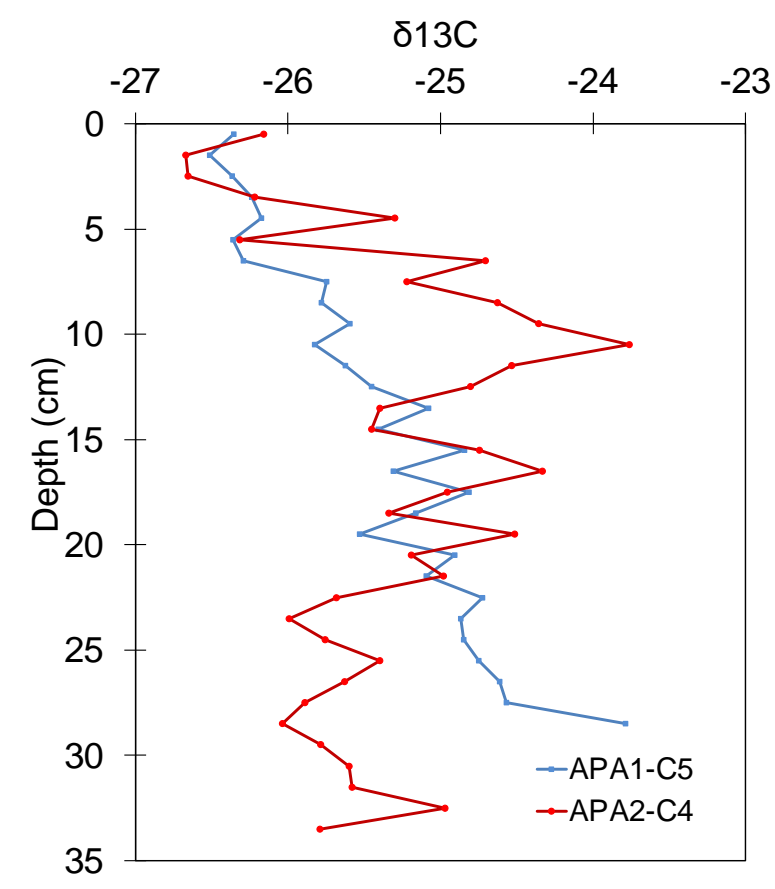

Figure 5: Carbon stable isotope of the Distichia peat from the APA1-C5 and APA2-C4 cores.

\section{Discussion}

\section{$195 \quad 5.1$ Carbon accumulation rates and the role of Distichia muscoides}

Carbon accumulation rates (CAR) calculated here for the Apacheta Peruvian peatlands are among the highest when compared to other peatlands worldwide (Fig. 6). When compared to other peatlands located in the Andes, the CARs from Apacheta are notably higher than the values found in Bolivia (47 and $37 \mathrm{~g} \mathrm{C} \mathrm{m}^{-2} \mathrm{yr}^{-1}$; Hribljan et al., 2015) and Ecuador (46 $\mathrm{g} \mathrm{C} \mathrm{m}^{-2} \mathrm{yr}^{-1}$, Chimmer \& Karberg, 2008; 43 and $224 \mathrm{~g} \mathrm{C} \mathrm{m}^{-2} \mathrm{yr}^{-1}$, Hribljan et al., 2016) with other cushion-forming dominant species: Distichia muscoides and Oxycholoe andina at the first site, and Azorella spp. and Distichia muscoides with Plantago rigida for the other two. On the other hand, CAR are in the same order of magnitude as those found in peatlands where Distichia muscoides is the dominant species in Bolivia (70 - $292 \mathrm{~g} \mathrm{C} \mathrm{m}^{-2} \mathrm{yr}^{-1}$, Cooper et al., 2015) and Colombia (150 - $200 \mathrm{~g}$ $\mathrm{C} \mathrm{m}^{-2} \mathrm{yr}^{-1}$, Benavides et al., 2013). Our results were also higher than those recorded in peatlands in western Canada (7 - 182 $\mathrm{g} \mathrm{C} \mathrm{m}^{-2} \mathrm{yr}^{-1}$; Yu et al., 2003), mountains of China (9 - $129 \mathrm{~g} \mathrm{C} \mathrm{m}^{-2} \mathrm{yr}^{-1}$; Xing et al., 2015) and United States (95.4 $\mathrm{g} \mathrm{C} \mathrm{m}^{-2}$ $205 \mathrm{yr}^{-1}$, Drexler et al., 2015), and also in temperate tropical peatlands (20 - $25 \mathrm{~g} \mathrm{C} \mathrm{m}^{-2} \mathrm{yr}^{-1}$; Cooper et al., 2010). They also are greater than rates found in tropical lowland Amazonian peatlands in Peru, where the values varied between 26 and $74 \mathrm{~g} \mathrm{C}$ $\mathrm{m}^{-2} \mathrm{yr}^{-1}$ for the first $175 \mathrm{~cm}$ of peatlands dominated by Mauritia flexuosa (Lähteenoja et al., 2009), and from tropical peatlands with Poaceae species in Brazil, where the rates were 151 and $243 \mathrm{~g} \mathrm{C} \mathrm{m}^{-2} \mathrm{yr}^{-1}$ for depths of 41 and $30 \mathrm{~cm}$, respectively (Lourençato et al., 2017). 
High CAR, found in Apacheta cores, shows a scenario of slow decomposition (with high mean organic matter contents of 94\%) and potentially rapid vegetal production along of all peat cores analyzed (mainly before the early 1980s), where accumulation rates reached up to $1.7 \mathrm{~cm} \mathrm{yr}^{-1}$ (Fig. 2). Consequently, during periods characterized by high accumulation rates, CAR values were up to $1010 \mathrm{~g} \mathrm{C} \mathrm{m}^{-2} \mathrm{yr}^{-1}$. In our study, these great CARs can be related to the high growth rates of Distichia muscoides, similar to previously reported values of up to $5 \mathrm{~cm} \mathrm{yr}^{-1}$ in the Bolivian peatlands (Cooper et al., 2015) 215 and $3 \mathrm{~cm} \mathrm{yr}^{-1}$ in Colombian peatlands (Benavides et al., 2013). Growth rates in Andean peatlands dominated by Distichia muscoides are also among the highest compared to other peatlands worldwide. High rates of growth, net primary production and $\mathrm{C}$ accumulation observed in Andean cushion systems dominated by D. muscoides are mainly the result of high rates of insolation in the dry Andes enhancing photosynthesis, a constantly supplied groundwater table near the surface, waters with a pH close to neutrality and high ions concentration, and finally anoxic and cold soils limiting decomposition (Squeo et al., 2006; Maldonado Fonkén, 2014; Cooper et al., 2015). These plants are characterized by rapid and continuous growth throughout the year (Cooper et al., 2015; Skrzypek et al., 2011). It has thick leaves and shoots of slow decomposition that leads to high concentrations of organic matter. Due to typical conditions of the high-Andean peatlands (anaerobic environment and low temperatures), their dead remains do not decompose rapidly, and the fossil tissues are deposited as a peat (Schittek et al., 2015).

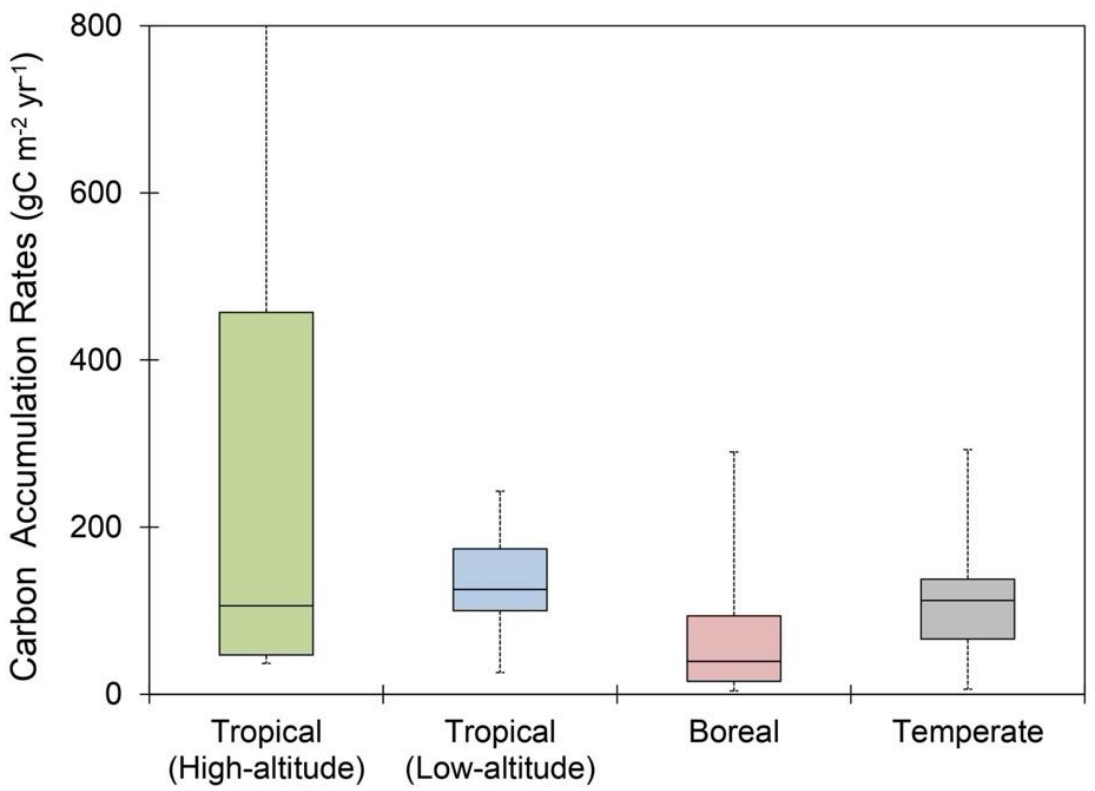

Figure 6: Comparison of carbon accumulation rates (CARs) between several peatlands around the world for the top 30cm, results of this study and a compilation for: tropical high-altitude (Chimmer and Karberg 2008, Salvador et al. 2014, Benavides et al. 2015, Cooper et al. 2015, Hribljan et al. 2015, Roa-García et al. 2016, Hribljan et al. 2016), tropical low-altitude (Lähteenoja et al. 2009, Turunen et al. 2001, Chimner and Cooper 2003, Turunen et al. 2004, Beilman et al. 2009, Van Bellen et al. 2011, Nakatsubo et al. 2014, Chimner et al. 2016), temperate (Xing et al. 2015, Bao et al. 2010). 
Differences found in CAR (Fig. 4) from the analyzed peatlands (APA 1 and APA 2) were related to the different drainage area surfaces, much larger for APA1 $\left(130 \mathrm{~km}^{2}\right)$ than for APA2 $\left(2.5 \mathrm{~km}^{2}\right)$ (Fig. 1) that influence the accumulation rates (higher for APA 1 than for APA 2) (Fig. 2). Peat formation by Distichia muscoides and its consequent C accumulation are also dependent on specific topographic factors, because they require topographic depressions that allow the accumulation of few or no mineral sedimentation (Kleinebecker et al., 2010), so the visible differences between CAR from the two Andean peatlands in this study (APA 1 and APA 2) could be also explained by their different local topography. Although there is a similar downward trend in the CAR at both sites after the early 1980s, before this period we observed a greater accumulation value for APA 1 (maximum value: $1010 \mathrm{~g} \mathrm{C} \mathrm{m}^{-2} \mathrm{yr}^{-1}$ ) than for the higher-altitude peatland ( $465 \mathrm{~g} \mathrm{C} \mathrm{m}^{-2} \mathrm{yr}^{-1}$ ). Therefore, favorable topographic conditions and the larger area of its sub-catchment for APA1 (Fig. 1B) that allowed greater water accumulation and a consequently higher water tables, which reduced the time when Distichia plants were exposed to aerobic decay, ensured peat conservation and resulted in higher CAR (Glaser et al., 2004; Cooper et al., 2015; Benfield et al., 2021).

\subsection{Climate controls over the last 65 years and their impact on the peatlands carbon accumulation}

Climate in the tropical and subtropical Andes is changing rapidly, marked by warming, melting of glaciers and changes in the seasonality of the precipitation, especially at higher elevations (Vuille et al., 2018). Hence regional climate changes and the consequent glacial retreat in the Andes could represent a threat to high-altitude peatlands, because tropical glaciers are the most important source of water to them, maintaining a steady supply and a stable water table around the year, especially in Distichia muscoides-dominated peatlands which are typically associated with glacial dynamics (Thompson et al., 2006; Benavides et al., 2013). The decrease of accumulation rates over the last 35 years (with values of about 0.6 and $0.4 \mathrm{~cm} \mathrm{yr}^{-1}$ for APA1 and APA2) may be related to an increase on decomposition rates due to temperature increase (Wieder, 2001; Benavides et al., 2013).

In our study area, the temperature shows an increase during the last 65 years, most marked over the last 30 years and for precipitation a marked interannual variability and a slight decrease of the total annual amount is observed over the last 65 years (Fig. 7).

So the decrease in the growth rate of peatlands after the early 1980s seems more related to temperature than precipitation. The effect of temperature can also be indirect and linked to the retreat of glaciers. Andean peatlands are influenced by hydrological conditions and are most abundant in areas with excess moisture (Mitsch and Gosselink, 2007; Charman et al., 2008; Klein et al., 2013). It has been shown that glacial withdrawal has also an influence in the Andean wetlands area and their connectivity (Polk et al., 2017). Changes in water balance due to variations in stream discharge dynamics related to glacial retreat should be expected to have effects on biomass production and biogeochemical cycles (Charman et al., 2008; Polk et al. 2017; Xia et al., 2020), and glacial melt water may feed some of the Distichia-dominated peatlands and buffer the general downward trend in the precipitation observed in recent decades elsewhere in the Andes (Benavides et al., 2013). At Apacheta, the glacial retreat over the last century could have fed the peatlands with melt water which would explain the high 
growth rates observed before the 70s. The subsequent reduction in peat growth rates could have been due in part to the decrease in the rate of water inflow from nearby glaciers to peatlands after their complete disappearance. These expected hydrological changes would reduce water availability for cushion-plant species in peatlands (as Distichia muscoides), influencing their production and survival (Cooper et al., 2015) also affecting CAR by the deceleration of its rates that occurred after the early 1980s for both analyzed peatlands (Fig. 4).

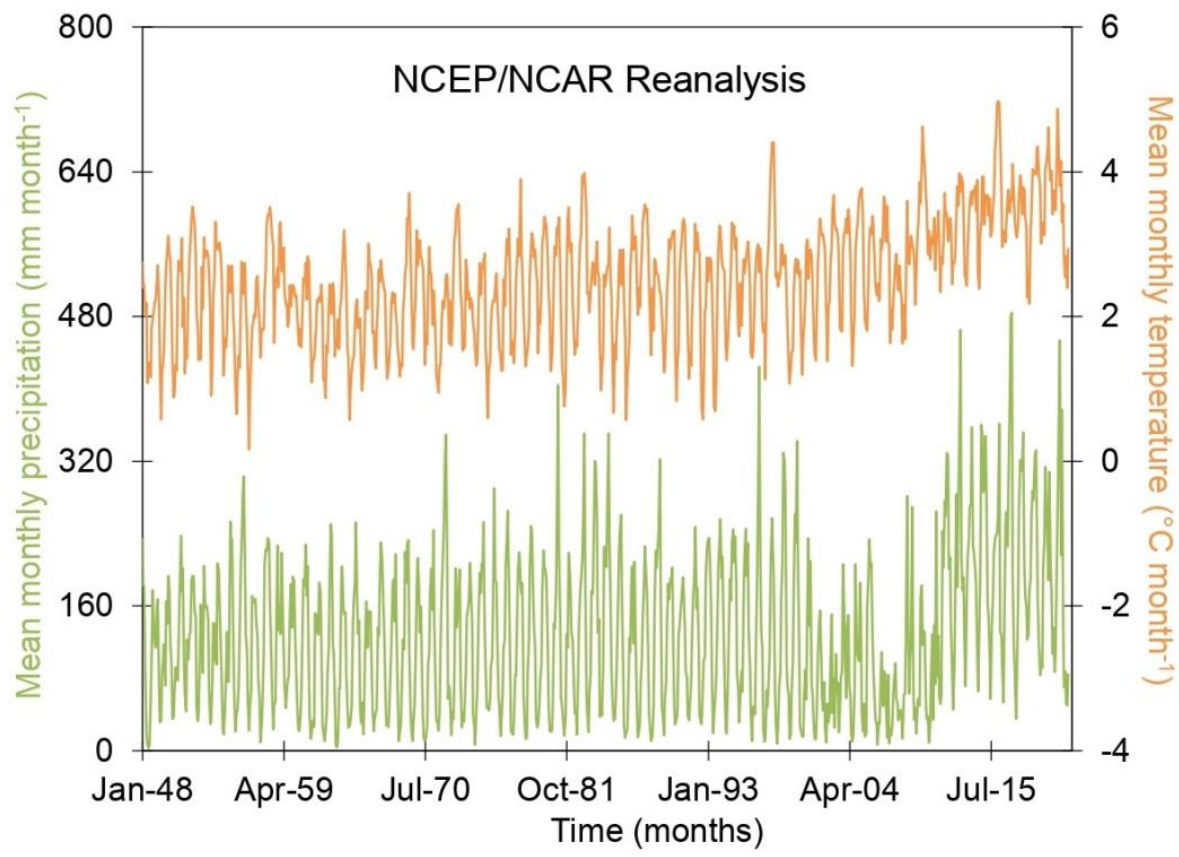

Figure 7: Monthly precipitation and temperature (at geopotential $600 \mathrm{mb}$ ) data over the 1948-2021 period from the NCEP/NCAR analysis.

Our results highlight the clear decrease of the $\delta^{13} \mathrm{C}$ from the bottom towards the top of all cores (Fig. 5). It has been shown that changes in mean air temperature have a direct effect on the composition of $\mathrm{C}$ stable isotope $\left(\delta^{13} \mathrm{C}\right)$ of Distichia peat (Skrzypek et al., 2011; Engel et al., 2014). Very strong gradients in $\delta^{13} \mathrm{C}$ with elevation, on the order of $0.4 \%$ per $100 \mathrm{~m}$, have been observed in Andean Distichia as well as in surface peat (Skrzypek et al., 2011). Part of this gradient may be due to the decrease in atmospheric $\mathrm{pCO}_{2}$ with altitude, but observations and theoretical calculations conducted in the Alpes show that this effect is small, less than $0.08 \% / 100 \mathrm{~m}$ (Menot and Burns, 2001). Furthermore, according to these authors, vascular plants can adapt to $\mathrm{CO}_{2}$ variations by changing their photosynthetic rate and stomatal conductance (leaf size, stomatal opening, stomatal density, etc.) which minimizes the effects of atmospheric $\mathrm{pCO}_{2}$ variations. The strong gradients in $\delta^{13} \mathrm{C}$ with elevation measured on Peruvian peatland Distichias are therefore interpreted as being primarily due to the temperature gradient and the impact of temperature on photosynthetic responses (Skrzypek et al., 2011). 


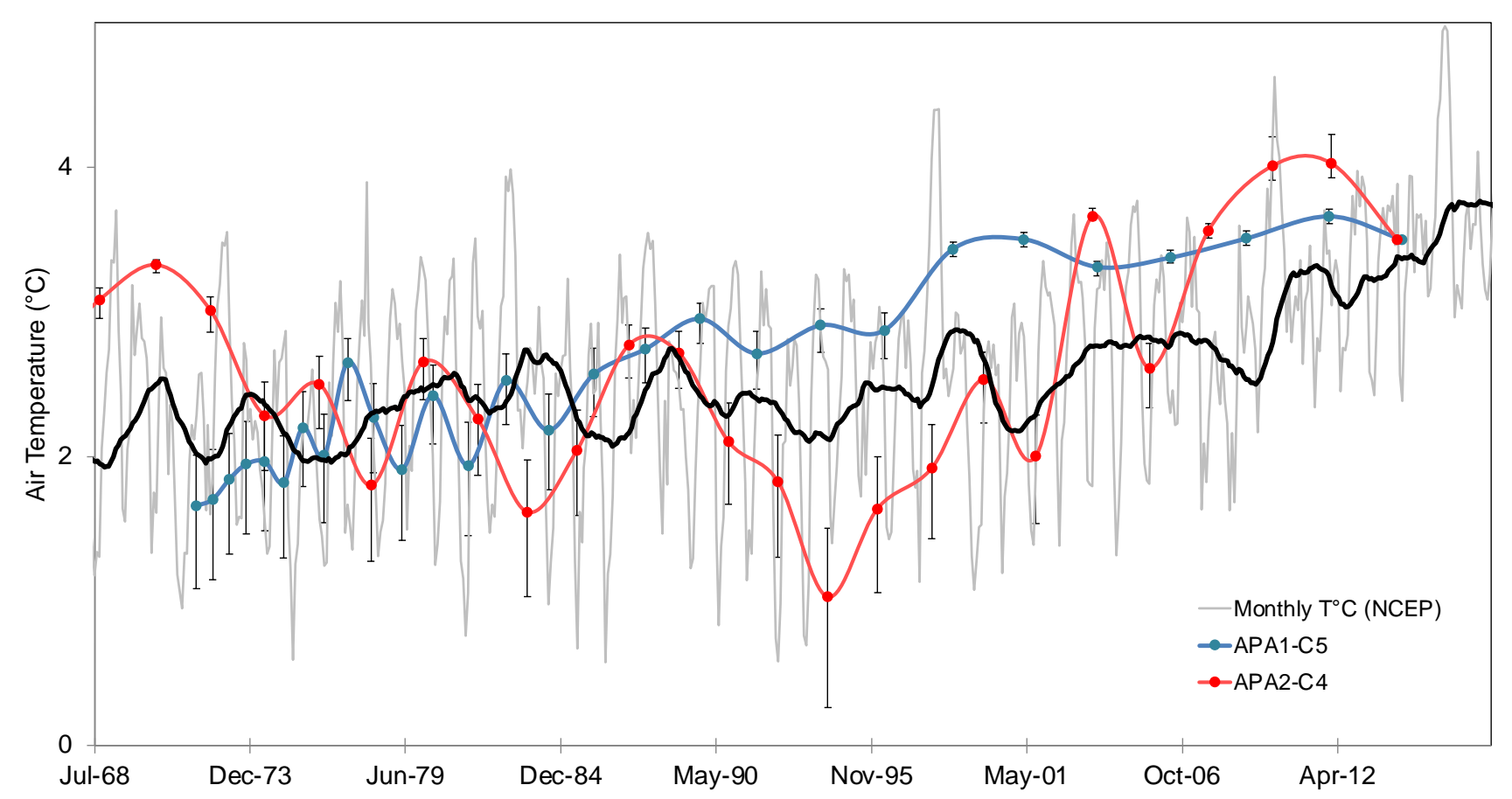

Figure 8: Monthly temperature from NCEP/NCAR analysis and two-year moving average (black line), reconstructed temperature using $\delta^{13} \mathrm{C}$ data from the two core samples APA1-C5 and APA2-C4.

The comparison made using the $\delta^{13} \mathrm{C}$ data to reconstruct the temperature in the study area and the NCEP temperature data showed a good relationship especially in trends. This confirms the use of this proxy for recent temperature reconstruction studies (Fig. 8). Of course, this comparison is difficult because the NCEP data are reanalysis data that may differ from the peatland temperatures themselves and because we do not know precisely what time period each peat sample corresponds to.

295 The NCEP data reanalysis, show a temperature increase average at the site of $2.15^{\circ} \mathrm{C}$ for the last 45 years and we observed a general trend of increase in the reconstructed temperature from both studied peatlands from 1.9 to $2{ }^{\circ} \mathrm{C}$ for the same period (1970-2015 CE).

The temperature increases and the decrease in CAR in the Peruvian Andes strongly suggest an increase in the rate of decomposition of organic matter. Recent results propose that microbial activity in peatlands increases with rising temperature, thus increasing decomposition (Bell et al., 2018; Galego-Sala et al., 2018). In this sense, temperature increase seems to be an unfavorable conservation condition for Distichia muscoides cushion plant-dominated Andean peatlands. Air temperature in tropical Andes is increasing fast, and massive warming of 4.5 to $5.0{ }^{\circ} \mathrm{C}$ is projected by the end of the $21 \mathrm{st}$ century under the IPCC A2 scenario (high emission) (Vuille et al., 2008), with a considerably rise not only in the temperature but in their interannual variability (Urrutia and Vuille, 2009). Because the climate is changing rapidly, there is 
https://doi.org/10.5194/bg-2022-47

Preprint. Discussion started: 21 February 2022

(c) Author(s) 2022. CC BY 4.0 License.

(c) (i)

305 an increasing need to understand how water and soil resources respond to climate change and what will be its consequences on the stability and distribution of the Andean ecosystems.

\section{Conclusion}

Distichia muscoides-dominated peatlands represent a significant $\mathrm{C}$ reservoir and consequently play an important role in the regional (and even global) $\mathrm{C}$ cycle, despite their small surface. This highlights the role of these peatlands as $\mathrm{C}$ sinks that contribute to the mitigation of global climate change. The CARs measured in this study are among the highest in the world. Rapid growth, slow decomposition and high accumulation rates are mainly responsible for the high CAR found in Andean peatlands over the last 65 years. Although this system still represents one of the most or the most important $\mathrm{C}$ reservoirs of the Andes, a clear decrease of this accumulation has been observed since the end of the 1970s.

This decline in $\mathrm{C}$ accumulation was mainly related to the temperature rise which increases the organic matter degradation

315 rate. Another effect of the temperature increase is the glacier retreat that potentially has fed with melting water and nutrients the peatlands inducing very high CAR. The decline of these inputs and the almost total disappearance of glaciers has probably contributed to the decrease of CAR in the last decades.

Our findings highlight that tropical Andean peatland seem to be one the most vulnerable ecosystem face to climate change. The relation between climate conditions and $\mathrm{C}$ accumulation suggests that future changes in the environment (such as 320 increasing temperatures, decreasing water inputs and glacial disappearance) may threaten the continuity of peatlands, especially in the high-mountain Andes, resulting in an uncertain future for these peatlands, which could perhaps go from being $\mathrm{C}$ stores to emitters. With the decline of peatlands, an important compartment of water storage in the Andes is also disappearing.

\section{Data availability}

The data associated with this manuscript will be submitted in the IRD database upon publication of this paper.

\section{Author contributions}

P.M.T with contribution of B.T. and B.W. designed the study project. Y.H. and R.E.V. planned fieldwork and collected 330 samples. R.L. analyzed the samples and processed the data. T.C. contributed to critical analysis of climatic data. R.L., P.M.T. and B.T. wrote the manuscript. All authors provided critical feedback and helped the final manuscript.

\section{Competing interests}

The authors declare that they have any competing interests. 
https://doi.org/10.5194/bg-2022-47

Preprint. Discussion started: 21 February 2022

(c) Author(s) 2022. CC BY 4.0 License.

(c) (i)

\section{Acknowledgements}

This research has been supported by the Institut de Recherche pour le Développement (IRD, France) and by the USAID Partnership for Enhanced Engagement in Research (PEER) program, through the projects: "Strengthening resilience of

340 Andean river basin headwaters facing global change" (PGA - 084063) and "AGUA - ANDES: Ecological Infrastructure Strategies for Enhancing Water Sustainability in the Semi-Arid Andes" (PGA - 174194); and the International Water Security Network funded by the Lloyd's Register Foundation. This work was also supported by the French National Program EC2CO (Ecosphère Continentale et Côtière). We are also grateful to the Agua - Andes Project team for their wonderful and helpful work during the collection of the cores. Romina Llanos's fellowship was financed by the MAGNET project "Clima, 345 paleoambientes y biodiversidad en sistemas marinos y acuáticos continentales" - Subproject N4 "Sensibilidad de los ecosistemas acuáticos de montaña frente a los cambios climáticos" (financially supported by Fondecyt - Peru).

\section{References}

Balslev, H.: Juncaceae: Flora Neotropica Monograph No. 68, The New York Botanical Garden Press, New York, 167 pp., ISBN-10: 0893274038, 1996.

350 Bell M. C., Ritson, J. P., Verhoef, A., Brazier, R. E., Templeton, M. R., Graham, N. J. D., Freeman, C., and Clark, J. M.: Sensitivity of peatland litter decomposition to changes in temperature and rainfall, Geoderma, 331, 29-37, doi:10.1016/j.geoderma.2018.06.002, 2018.

Benavides, J. C., Vitt, D. H., and Wieder, R. K.: The influence of climate change on recent peat accumulation patterns of Distichia muscoides cushion bogs in the high-elevation tropical Andes of Colombia, J. Geophys. Res. Biogeosci., 118(4), 355 1627-1635, doi:10.1002/2013JG002419, 2013.

Benfield, A. J., Zicheng Yu, Z., and Benavides, J. C.: Environmental controls over Holocene carbon accumulation in Distichia muscoides-dominated peatlands in the eastern Andes of Colombia, Quat. Sci. Rev., 251, 106687, doi:10.1016/j.quascirev.2020.106687, 2021.

Blaauw, M.: Methods and code for 'classical' age-modelling of radiocarbon sequences, Quat. Geochronol, 5, 512-518, doi:10.1016/ j.quageo.2010.01.002, 2010.

Buffen, A. M., Thompson, L. H., Mosley-Thompson, E., and In Huh, K.: Recently exposed vegetation reveals Holocene changes in the extent of the Quelccaya Ice Cap, Peru, Quat., 72, 157-163, doi:10.1016/ j.yqres.2009.02.007, 2009.

Charman, D. J., Booth, R. K., Mäkilä, M., and Sirin, A.: Peatlands and Past Climate Change. In: Assessment on Peatlands, Biodiversity and Climate Change: Main Report, edited by: Parish, F., Sirin, A., Charman, D., Joosten, H., Minayeva, T., 365 Silvius, M., and Stringer, L., Global Environment Centre, Kuala Lumpur and Wetlands International, Wageningen, 39-59, 2008.

Charman, D. J., Beilman, D. W., Blaauw, M., Booth, R. K., Brewer, S., Chambers, F. M., Christen, J. A., Gallego-Sala, A., Harrison, S. P., Hughes, P. D. M., Jackson, S. T., Korhola, A., Mauquoy, D., Mitchell, F. J. G., Prentice, I. C., Van Der 
https://doi.org/10.5194/bg-2022-47

Preprint. Discussion started: 21 February 2022

(c) Author(s) 2022. CC BY 4.0 License.

\section{(c) (i)}

Linden, M., De Vleeschouwer, F., Yu, Z. C., Alm, J., Bauer, I. E., Corish, Y. M. C., Garneau, M., Hohl, V., Huang, Y.,

Karofeld, E., Le Roux, G., Loisel, J., Moschen, R., Nichols, J. E., Nieminen, T. M., MacDonald, G. M., Phadtare, N. R., Rausch, N., Sillasoo, U., Swindles, G. T., Tuittila, E. S., Ukonmaanaho, L., Väliranta, M., Van Bellen, S., Van Geel, B., Vitt, D. H., and Zhao, Y.: Climate-related changes in peatland carbon accumulation during the last millennium, Biogeosciences, 10(2), 929-944, doi:10.5194/bg-10-929-2013, 2013.

Chevallier, P., Pouyaud, B., Suarez, W., and Condom, T.: Climate change threats to environment in the tropical Andes: glaciers and water resources, Reg. Environ. Change, 11, 179-187, doi:10.1007/s10113-010-0177-6, 2010.

Chimner, R. A., and Karberg, J. M.: Long-term carbon accumulation in two tropical mountain peatlands, Andes Mountains, Ecuador. Mires and Peat 3, Article 04, 1-10, ISSN 1819-754X, 2008.

Cooper, D.J., Kaczynski, K., Slayback, D., and Yager, K.: Growth and organic carbon production in peatlands dominated by Distichia muscoides, Bolivia, South America, Arct. Antarct. Alp. Res., 47 (3), 505-510, doi:10.1657/AAAR0014-060, 2015.

Engel, Z., Skrzypek, G., Chuman, T., Sefrna, L., and Mihaljevic, M.: Climate in the Western Cordillera of the Central Andes over the last 4300 years, Quat. Sci. Rev., 99, 60-77, doi:10.1016/j.quascirev.2014.06.019, 2014.

Gallego-Sala, A. V., Charman, D. J., Brewer, S., Page, S. E., Prentice, I. C., Friedlingstein, P., Moreton, S., Amesbury, M. J., Beilman, D. W., Björck, S., Blyakharchuk, T., Bochicchio, C., Booth, R. C., Bunbury, J., Camill, P., Carless, D., Chimner, R. A., Clifford, M., Cressey, E., Courtney-Mustaphi, C., De Vleeschouwer, F., de Jong, R., Fialkiewicz-Koziel, B.,

Finkelstein, S. A., Garneau, M., Githumbi, E., Hribjlan, J., Holmquist, J., Hughes, P. D. M., Jones, C., Jones, M. C., Karofeld, E., Klein, E. S., Kokfelt, U., Korhola, A. Lacourse, T., Le Roux, G., Lamentowicz, M., Large, D., Lavoie, M., Loisel, J., Mackay, H., MacDonald, G. M., Makila, M., Magnan, G., Marchant, R., Marcisz, K., Martínez Cortizas, A., Massa, C., Mathijssen, P., Mauquoy, D., Mighall, T., Mitchell, F. J. G., Moss, P., Nichols, J., Oksanen, P. O., Orme, L., Packalen, M. S., Robinson, S., Roland, T. P., Sanderson, N. K., Sannel, A. B. K., Silva-Sánchez, N., Steinberg, N., Swindles, G. T., Turner, T. E., Uglow, J., Väliranta, M., van Bellen, S., van der Linden, M., van Geel, B., Wang, G., Yu, Z., ZaragozaCastells, J., and Yan Zhao: Latitudinal limits to the predicted increase of the peatland carbon sink with warming, Nat. Clim. Change, 8, 907-913, doi:10.1038/s41558-018-0271-1, 2018.

Glaser, P. H., Hansen, B. C. S., Siegel, D. I., Reeve, A. S., and Morin, P. J.: Rates, pathways and drivers for peatland development in the Hudson Bay Lowlands, northern Ontario, Canada, Journal of Ecology, 92, 1036-1053, doi:10.1111/j.0022-0477.2004.00931.x, 2004.

GORE Ayacucho (Gobierno Regional de Ayacucho, PE): Base de datos metereológicos: Estación Apacheta - Planilla mensual, Peru, 2015.

Hua, Q., Barbetti, M., and Rakowski, A. Z.: Atmospheric Radiocarbon for the Period 1950-2010, Radiocarbon, 55 (4), 2059-2072, doi:10.2458/azu_js_rc.v55i2.16177, 2013.

400 Jomelli, V., Favier, V., Rabatel, A., Brunstein, D., Hoffmann, G., and Francou, B.: Fluctuations of glaciers in the tropical Andes over the last millennium and palaeoclimatic implications: A review, Palaeogeogr. Palaeoclimatol. Palaeoecol., 281, 269-282, doi:10.1016/j.palaeo.2008.10.033, 2009. 
https://doi.org/10.5194/bg-2022-47

Preprint. Discussion started: 21 February 2022

(c) Author(s) 2022. CC BY 4.0 License.

(c) (i)

Kaser, G., and Ostmaston, H. A.: Tropical Glaciers, UNESCO international hydrology series, Cambridge University Press, Cambridge, UK. 207 pp., ISBN 052163333 8, 2002.

Klein, E. S., Yu, Z., and Bootha, R. K.: Recent increase in peatland carbon accumulation in a thermokarst lake basin in southwestern Alaska, Palaeogeogr. Palaeoclimatol. Palaeoecol., 392, 186-195, doi:10.1016/j.palaeo.2013.09.009, 2013.

Kleinebecker, T., Hölzel, N., and Vogel, A.: Patterns and gradients of diversity in South Patagonian ombrotrophic peat bogs, Austral Ecol., 35, 1-12, doi:10.1111/j.1442-9993.2009.02003.x, 2010.

Lähteenoja, O., Ruokolainen, K., Schulman, L., and Oinonen, M.: Amazonian peatlands: An ignored C sink and potential source. Glob. Change Biol., 15, 2311-2320, doi:10.1111/j.1365-2486.2009.01920.x, 2009.

Maldonado Fonkén, M.S.: An introduction to the bofedales of the Peruvian High Andes, Mires and Peat, 15, 1-13, ISSN 1819-754X, 2014.

Ménot, G. and Burns, S.J.: Carbon isotopes in ombrogenic peat bog plants as climatic indicators: calibration from an altitudinal transect in Switzerland. Org. Geochem., 32, 233-245, doi:10.1016/S0146-6380(00)00170-4, 2001.

415 Muñoz García, M.A., and Faz Cano, A.: Soil organic matter stocks and quality at high altitude grasslands of Apolobamba, Bolivia, Catena, 94, 26-35, doi:10.1016/j.catena.2011.06.007, 2012.

Pan, Y., Birdsey, R. A., Fang, J., Houghton, R., Kauppi, P. E., Kurz, W. A., Phillips, O. L., Shvidenko, A., Lewis, S. L., Canadell, J. G., Ciais, P., Jackson, R. B., Pacala, S. W., McGuire, A. D., Piao, S., Rautiainen, A., Sitch, S., and Hayes, D.: A Large and Persistent Carbon Sink in the World's Forests, Science, 333(6045), 988-993, doi:10.1126/science.1201609, 2011.

Polk, M.H., Young, K.R., Baraer, M., Mark, B.G., McKenzie, J.M., Bury, J., and Carey, M.: Exploring hydrologic connections between tropical mountain wetlands and glacier recession in Peru's Cordillera Blanca, Appl. Geogr., 78, 94103, doi:10.1016/j.apgeog.2016.11.004, 2017.

Rabatel, A., Francou, B., Soruco, A., Gomez, J., Cáceres, B., Ceballos, J. L., Basantes, R., Vuille, M., Sicart, J.-E. Huggel, C., Scheel, M., Lejeune, Y., Arnaud, Y., Collet, M., Condom, T., Consoli, G., Favier, V., Jomelli, V., Galarraga, R., Ginot, P., Maisincho, L., Mendoza, J., Ménégoz, M., Ramirez, E., Ribstein, P., Suarez, W., Villacis, M., and Wagnon, P.: Current state of glaciers in the tropical Andes: a multi-century perspective on glacier evolution and climate change, The Cryosphere, 7, 81-102, doi:10.5194/tc-7-81-2013, 2013.

Schittek, K., Forbriger, M., Mächtle, B., Schäbitz, F., Wennrich, V., Reindel, M., and Eitel, B.: Holocene environmental changes in the highlands of the southern Peruvian Andes (14 $\mathrm{S}$ ) and their impact on pre-Columbian cultures, Clim. Past, 11, $430 \quad$ 27-44, doi:10.5194/cp-11-27-2015, 2015.

Schittek, K., Forbriger, M., Berg, D., Hense, J., Schäbitz, F., and Eitel, B.: Last millennial environmental dynamics in the western Peruvian Andes inferred from the development of a cushion-plant peat hillock. Perspect. Plant Ecol. Evol. Syst., 30, 115-124, doi:10.1016/ j.ppees.2017.09.002, 2018.

Skrzypek, G., Engel, Z., Chuman, T., and Sefrna, L.: Distichia peat - A new stable isotope paleoclimate proxy for the Andes,

Earth Planet. Sci. Lett., 307, 298-308, doi:10.1016/j.eps1.2011.05.002, 2011. 
https://doi.org/10.5194/bg-2022-47

Preprint. Discussion started: 21 February 2022

(c) Author(s) 2022. CC BY 4.0 License.

(c) (i)

Squeo, F. A., Warner, B. G., Aravena, R., and Espinoza, D.: Bofedales: High altitude peatlands of the central Andes, Rev. Chil. Hist. Nat., 79, 245-255, doi:10.4067/S0716-078X2006000200010, 2006.

Urrutia, R., and Vuille, M.: Climate change projections for the tropical Andes using a regional climate model: temperature and precipitation simulations for the end of the 21st century, J. Geophys. Res. Atmos., 114, 1-15, 440 doi:10.1029/2008JD011021, 2009.

Vuille, M., Bradley, R. S., Werner, M., and Keimig, F.: 20th Century climate change in the Tropical Andes: observations and model results, Clim. Change, 59, 75-99, doi:10.1023/A:1024406427519, 2003.

Vuille, M., Francou, B., Wagnon, P., Juen, I., Kaser, G., Mark, B., and Bradley, R.: Climate change and tropical Andean glaciers: past, present, and future, Earth-Sci. Rev., 89, 79-96, doi:10.1016/j.earscirev.2008.04.002, 2008.

445 Vuille, M., Carey, M., Huggel, C., Buytaert, W., Rabatel, A., Jacobsen, D., Soruco, A., Villacis, M., Yarleque, C., Timm, O. E., Condom, T., Salzmann, N., and Sicart, J. E.: Rapid decline of snow and ice in the tropical Andes - Impacts, uncertainties and challenges ahead. Earth-Sci. Rev., 176, 195-213, doi:10.1016/j.earscirev.2017.09.019, 2018.

Wieder, R. K.: Past, present, and future peatland carbon balance: An empirical model based on 210Pb-dated cores, Ecol. Appl., 11, 327-342, doi:10.2307/3060892, 2001.

450 Xia, Z., Oppedal, L. T., Van der Putten, N., Bakke, J., and Yu, Z.: Ecological response of a glacier-fed peatland to late Holocene climate and glacier changes on subantarctic South Georgia, Quat. Sci. Rev., 250, 106679, doi:10.1016/j.quascirev.2020.106679, 2020.

Xing, W., Bao, K., Gallego-Sala, A. V., Charman, D. J., Zhang, Z., Gao, C., Lu, X., and Wang, G.: Climate controls on carbon accumulation in peatlands of Northeast China, Quat. Sci. Rev., 115, 78-88, doi:10.1016/ j.quascirev.2015.03.005, 4552015.

Xu, J., Morris, P. J., Liu, J., and Holden, J.: PEATMAP: refining estimates of global peatland distribution based on a metaanalysis, Catena, 160, 134-140, doi:10.1016/j.catena.2017.09.010, 2018.

Yu, Z., Campbell, I. D., Campbell, C., Vitt, D. H., Bonds, G. C., and Apps, M. J.: Carbon sequestration in western Canadian peat highly sensitive to Holocene wet-dry climate cycles at millennial timescales, The Holocene, 13, 801-808, 460 doi:10.1191/0959683603hl667ft, 2003.

Yu, Z., Loisel, J., Brosseau, D. P., Beilman, D. W., and Hunt, S. J.: Global peatland dynamics since the Last Glacial Maximum, Geophys. Res. Lett., 37, L13402, 1-5, doi:10.1029/2010GL043584, 2010.

Yu, Z., Charman, D., Beilman, D., and Nichols, J.: Understanding peat carbon sequestration on Earth, Past Global Changes, 24, 37, doi:10.22498/pages.24.1.3, 2016. 